\title{
PSYCHOLOGICAL BENEFITS OF EXERCISE AND PHYSICAL ACTIVITY IN OLDER ADULTS
}

\author{
Petra DOLENC ${ }^{1} \&$ Mojca PETRIČ ${ }^{2}$ \\ ${ }^{1}$ University of Primorska, Faculty of Education, Koper, Slovenia \\ ${ }^{2}$ Psychiatric Hospital Begunje, Slovenia \\ Corresponding Author: \\ Petra DOLENC \\ University of Primorska, Faculty of Education, Cankarjeva 5, 6000 Koper, Slovenia \\ Phone: +38656631252 \\ E-mail: petra.dolenc@pef.upr.si
}

ABSTRACT

While regular physical activity has been shown to positively impact health and physical functioning across all age groups an active lifestyle may in particular have beneficial effects in advanced age. The objective of this article is to provide a brief overview of a contemporary research on the benefits of physical activity for psychological health and quality of life in the elderly. Older adults are more vulnerable than other age groups regarding mental health problems, such as depression and anxiety. Many cross-sectional and experimental studies discussed in the article confirm the importance of a physically active lifestyle for preventing or reducing mental health problems and improving the quality of life among elderly people.

Keywords: mental health, physical activity, quality of life, late adulthood.

\section{POZITIVNI PSIHOLOŠKI UČINKI GIBALNE/ŠPORTNE AKTIVNOSTI PRI STAREJŠIH ODRASLIH}

\section{IZVLE ¿̌EK}

Redna gibalna/športna aktivnost pozitivno vpliva na gibalne zmogljivosti in zdravje posameznikov v vseh starostnih skupinah, predvsem pa ima aktivni življenjski slog lahko ugodne učinke v obdobju starosti. Namen prispevka je predstaviti pregled literature 
Petra DOLENC, Mojca PETRIČ: PSYCHOLOGICAL BENEFITS OF EXERCISE AND PHYSICAL ACTIVITY IN OLDER ADULTS, 121-134

s področja preučevanja koristi gibalne aktivnosti za psihološko zdravje in kakovost življenja pri starejših odraslih. Slednji so v primerjavi z drugimi posamezniki bolj dovzetni za različne težave $v$ duševnem zdravju, kot sta depresija in anksioznost. Številne presečne in eksperimentalne študije, o katerih razpravljamo v prispevku, ugotavljajo, da je aktivni življenjski slog ključen za preprečevanje ali zmanjšanje težav v duševnem zdravju ter izboljšanje kakovosti življenja pri starejši populaciji.

Ključne besede: duševno zdravje, gibalna aktivnost, kakovost življenja, pozna odraslost

\section{INTRODUCTION}

It is becoming increasingly apparent that successful aging is possible if people maintain certain healthy lifestyle habits throughout their lives (Mora, 2013). Among these habits, we also include physical activity (PA). According to the World Health Organization (WHO, 2015), a regular PA among older people is highly recommended for the promotion of an active lifestyle: older adults should participate in at least 50 minutes of moderate intensity and 75 minutes of vigorous intensity level PA per week.

In a number of recent studies, PA has been identified as a key factor for improving health and quality of life in older adults (Daskalopoulou et al., 2017; Gill et al., 2013; Murtagh et al., 2014). As population aging is progressing rapidly in many industrialized countries, it is important to understand the relationship between PA and the physical and mental well-being of older people (King \& King, 2010).

The health benefits of PA in older adults have been well established in the scientific literature (Musich, Wang, Hawkins, \& Greame, 2017). Regular PA can reduce the morbidity and mortality from many chronic diseases, postpone disability and prolong independent living (Kokkinos, 2012; Warburton \& Bredin, 2017). There is good evidence that being physically active reduces the risk of developing cardiovascular and metabolic disease through better control of blood pressure, cholesterol and waist circumference (Earnest et al., 2013). Physical activities and exercise programmes are important for building and maintaining bone density; they also improve neuromuscular capacity, increasing strength and muscle mass, which in turn may reduce the risk of falls (Meléndez-Ortega, 2007). PA is also associated with a reduction in age-related diseases such as dementia and Alzheimer's disease (Reiner, Niermann, Jekauc, \& Woll, 2013). Conversely, prolonged sedentary behaviour is associated with deleterious health outcomes, including cardiovascular disease incidence and mortality, type II diabetes and cancer incidence (Biswas et al., 2015).

In addition to all the positive effects on physical health, there is growing evidence that PA is beneficial for mental health, well-being (Mochcovitch, Deslandes, Freire, Garcia, \& Nardi, 2016; Netz, Wu, Becker, \& Tenenbaum, 2005) and even cognitive functioning (Colcombe \& Kramer, 2003; Gajewski \& Falkenstein, 2016) in older 
Petra DOLENC, Mojca PETRIČ: PSYCHOLOGICAL BENEFITS OF EXERCISE AND PHYSICAL ACTIVITY IN OLDER ADULTS, 121-134

adults. Multiple studies have found a positive association between exercise and PA and the alleviation of symptoms of anxiety and depression (Lee et al., 2014; Lindwall, Rennemark, Halling, Berglund, \& Hassmén, 2007).

\section{OBJECTIVES}

The purpose of this contribution is to present an overview of empirical literature regarding the benefits of PA on mental health and well-being, the possible mechanisms explaining PA effects on mental health and the association between PA and quality of life in the elderly.

Electronic databases PubMed, PsycINFO, Scopus, and SPORTDiscus were searched for literature sources in May 2018 for the last two decades (between 1997 and 2017 inclusive). Different keywords were used: physical activity, exercise, mental health, quality of life, psychological well-being, older adults.

\section{PHYSICAL ACTIVITY EFFECTS ON MENTAL HEALTH AND WELL-BEING IN OLDER ADULTS}

The aging process is associated with an increased prevalence of both physical and mental health concerns (Wrosch, Schult, Miller, Lupien, \& Dunne, 2007). Poor mental health is an important consideration for older adults, since it seems to be a substantial component of the perceived quality of life and can also affect health status (Cho, Martin, Margrett, MacDonald, \& Poon, 2011).

Depression is the most common mental disorder in this age group, which affects approximately $5 \%$ and $7 \%$ of the world's older population (WHO, 2016) although significant depressive symptoms (which do not meet the diagnostic criteria for major depression) are much more prevalent among community-dwelling old adults. Mental health problems in later life are under-identified by health professionals and by older people themselves; therefore, to promote well-being in later life, it seems crucial to prevent or adequately address mental health problems. Given the high cost of health care and prescription medication, it is important to consider the relationships between the modifiable behaviours and lifestyles that might affect the mental health, such as PA (Parker, Strath, \& Swartz, 2008).

Penninx and colleagues (2002) examined the exercise effects on emotional function in 438 older participants with high and low depressive symptomatology. After an 18-month walking program, a significant reduction of depressive symptoms (assessed by the Centre for Epidemiologic Studies Depression scale - CES-D; Radloff, 1977) was reported for both persons with initially high and low depressive symptomatology, hinting at the possible antidepressant effect of PA. These findings illustrate that aerobic exercise may have significant beneficial emotional effects among the general older population. In a similar study conducted by Blumenthal et al. (1999), a 16-week 
randomized controlled trial was performed to assess the effectiveness of an aerobic exercise program compared with standard medication for treatment of older patients with major depressive disorder. One hundred fifty-six men and women were assigned randomly to a program of aerobic exercise, antidepressants, or combined exercise and medication. Anxiety was assessed using the Hamilton Rating Scale for Depression (HAM-D; Linden, Borchelt, Barnow, \& Geiselman, 1995) and the Beck Depression Inventory (BDI; Beck, Steer, \& Garbin, 1988). The investigators demonstrated that exercise training program including supervised sessions of walking and jogging are equally as effective as a standard antidepressant therapy in reducing depression symptoms among older clinically depressed persons (Blumenthal et al., 1999). Some authors also emphasize that traditional treatments for depression such as psychotherapy and antidepressant medications are not effective for all patients, therefore, alternative approaches are recommended, especially the use of aerobic exercise (Blumenthal, Smith, \& Hoffman, 2012).

In a recent meta-analytic study, Silveira and colleagues (2013) evaluated the effect of aerobic training and strength training as a treatment for depression in patients diagnosed with major depressive disorder. The meta-analysis concluded that physical exercise, mainly aerobic training, improves the response to depression treatment. However, the efficacy of exercise in the treatment of depression was influenced by age and severity of symptoms.

Mummery and colleagues (2004) examined the dose-response relationship between PA and mental health, comparing different levels of PA involvement. The study included 337 independent living older adults ranging from 55 to 89 years of age. Activity status was assessed using the Active Australia questionnaire, whereas health status was assessed using the 12-Item Short Form Health Survey (SF-12; Jenkinson, Chandola, Coulter, \& Bruster, 2001). Participants in the moderately active group (150-420 minutes of PA per week) and highly active group ( $>420$ minutes of PA per week) displayed significantly higher mental health status than those who were classified as inactive $(<150$ minutes of PA per week) when controlling for physical health status. A meta-analytic study conducted by Conn (2010) synthesized depressive symptom outcomes of 38 supervised and 22 unsupervised PA interventions among healthy adults. The obtained findings showed that both supervised and unsupervised PA interventions are effective in reducing depressive symptoms among adults without clinical depression.

In a recent longitudinal study, the relationship between the quantity and type of PA and subsequent depression in 3,497 adults aged between 65 and 75 was examined. Total PA was measured using the Physical Activity Scale for the Elderly (PASE; Washburn, McAuley, Katula, Mihalko, \& Boileau, 1999), while depressive symptoms were measured by the Patient Health Questionnaire (PHQ-9; Martin, Rief, Klaiberg, $\&$ Braehler, 2006). The participants who practised the highest levels of PA and whose activity profile included athletic activity were at lower risk for depression in older age (Joshi et al., 2016).

Given the prevalence of depressive symptoms and the low rate of diagnosis among older adults, the promotion and maintenance of moderate-intensity aerobic PA could be 
a recommended way for improving psychological well-being for all older people (Bridle, Spanjers, Patel, Atherton, \& Lamb, 2012; Lee et al., 2014; Mummery, Schofield, \& Caperchione, 2004).

Watanabe and colleagues (2000) examined the effect of an acute PA program of different exercise conditions on the level of anxiety among older adults. Seventy-three healthy participants were randomly assigned to either water exercise group or land exercise group. The state of anxiety was assessed before and after the exercise. The obtained results showed that both exercise groups scored lower on anxiety after exercise, suggesting that the participation in these types of exercise can help to reduce anxiety levels in older persons. Moreover, in a meta-analytic review of cross-sectional studies, a greater amount of physical exercise was associated with preferable levels of both positive and negative effects (Arent, Landers, \& Etnier, 2000). Stubbe and colleagues have found that accumulating more PA is correlated with higher satisfaction with life (Stubbe et al., 2007).

The effects of regular PA on the person's mood have mainly been studied using aerobic exercise but evidence indicates that other types of exercise, such as strength or flexibility training, can also reduce depressive symptoms, while less consensus exists with respect to anxiety symptoms (Peluso \& Andrade, 2005). Chodzko-Zajko and colleagues (2009) reported that both aerobic exercise training and resistance exercise training produce clinically meaningful improvements in depression in clinical patients, with response rates ranging from $25 \%$ to $88 \%$, whereas the findings are less consistent among the seniors without clinical depression.

In a recent systematic review, Mochcovitch and colleagues (2016) evaluated the efficacy of regular PA on anxiety symptoms in older adults without anxiety disorders. All analysed studies have shown that regular and supervised PA was directly related to decreased anxiety symptoms in older individuals. The authors concluded that regular PA may be effective for reducing anxiety levels in older adults, however, more studies are needed to identify the ideal PA modality, frequency, duration and intensity for optimizing the positive effects of exercise on anxiety in this population.

Although research consistently points to an inverse correlation between exercise and mental health, some authors indicated conflicting results it this relationship, emphasizing the importance of instrumentation used to measure PA (Parker et al., 2008). Due to lower complexity and relative low cost, most studies use subjective techniques, such as questionnaires, to assess PA. In general, subjective methods are accurate for measuring structured exercise but tend to overestimate moderate and vigorous PA and underestimate sedentary behaviour (Dyrstad, Hansen, Holme, \& Anderssen, 2014). On the other hand, objective PA measures (i.e., pedometers, accelerometers) are increasingly used to evaluate the relationship between PA and mental health in older adults (Fox, McKenna, \& Davis, 2007; Loprinzi, 2013). Parker and colleagues (2008) examined the relationship between one week of PA and mental health among 84 adults aged 55 to 87 as measured by pedometers, accelerometers and the PASE questionnaire. Objective PA assessment instruments were more sensitive in detecting the small but significant relationship between PA and mental health (in terms of positive affect, negative affect, 
and satisfaction with life) relative to the subjective PA measurement technique. These results suggest that objective instruments may be preferable for assessing PA patterns among older adults. A study conducted by Loprinzi (2013) examined the association between accelerometer-assessed PA and depression symptoms among 708 older adults (65+ years). They wore an accelerometer for at least four days, and completed data on the study covariates along with depression, as assessed by the PHQ-9. After controlling for age, gender, race-ethnicity, body mass index, marital status, education, comorbidity index, and physical functioning, both light, and moderate-to-vigorous intensity PA was associated with lower depression levels.

\section{MECHANISMS UNDERLYING THE RELATIONSHIP BETWEEN PHYSICAL ACTIVITY AND MENTAL HEALTH}

The relationship between PA and mental health has been widely investigated and several hypotheses including neurobiological, psychological and social mechanisms have been proposed to explain this relationship (Deslandes et al., 2009; Lubans et al., 2016). Physiological mechanisms that are often discussed involve monoamine, endorphin and thermogenic hypothesis (Mikkelsen et al., 2017). Exercise is associated with the increased synthesis and release of both neurotransmitters and neurotrophic factors, and these increases may be associated with neurogenesis, angiogenesis and neuroplasticity (Matta Mello Portugal et al., 2013). The monoamine hypothesis proposes that exercises lead to balanced levels of neurotransmitters (such as dopamine, serotonin, and norepinephrine) which are usually imbalanced in people suffering from depression. Therefore, this hypothesis suggests that PA can work in a similar way as anti-depressants, medications that can help relieve symptoms of depression (Toups et al., 2011). The thermogenic hypothesis states that PA facilitates an increase in body temperature. Consequently, the increased temperature in specific brain region can lead to a more relaxed state, and, consequently, mood enhancement (DeBoer, Powers, Utschig, Otto, \& Smits, 2012). The endorphin hypothesis originated from runners experiencing a feeling of euphoria or high after long distances. It states that the release of $\beta$-endorphins in the brain following exercise produces a morphine-like effect which reduces the sensation of pain and provides a state of positive mood and an overall enhanced sense of wellbeing (Dishman \& O’Connor, 2009).

Alternatively, psychological mechanisms for positive changes in mood and effect as a result of PA include the distraction hypothesis and the self-efficacy hypothesis (Peluso \& Andrade, 2005; Shaw, Gorely, \& Corban, 2005). The distraction hypothesis suggests that exercise distracts people from depressive worries and negative thoughts. Participating in PA or other distracting activities (e.g. relaxation, social contacts) gives people a break from daily hassles and stressors and provide the opportunity to relax and perhaps put things in perspective. (Peluso \& Andrade, 2005). The self-efficacy hypothesis is centred on the notion that exercise brings better physical competence which results in positive feelings of achievement, increased sense of ability and self-confidence. While 
these feelings are associated specifically to the exercise domain, it is hypothesized that they may generalize to other areas of life, resulting in an increase of psychological well-being (Shaw et al., 2005).

The social interaction hypothesis proposes that social interaction and support from other people in an exercise setting provides a significant proportion of the PA effect on mental health (Crone, Smith, \& Gough, 2009). Research confirmed the relationship between social network ties and positive mental state in the older population, showing that people who are more socially connected tend to report greater emotional wellbeing compared to those who have fewer social ties (Litwin \& Shiovitz-Ezra, 2011). Especially for some excluded groups, such as older people or people with depression, the opportunity for social interaction may be particularly important for their psychological health.

\section{PHYSICAL ACTIVITY AND QUALITY OF LIFE IN OLDER ADULTS}

An important component in determining the health status of an individual, particularly during the process of aging, is quality of life (QoL). QoL is a global, multidimensional construct representing overall relative satisfaction with life. The concept of QoL includes different domains such as functional ability, psychological well-being, social relationships, socioeconomic status, living environment, daily activities, health, cultural and ethical values (Bowling, 2005). Older adults are often more concerned with their QoL than their longevity per se, so improving and maintaining a high QoL assumes great importance among the elderly. Because QoL is adversely impacted by illness and disability, an improved physical function might be expected to cause a parallel increase in QoL (Fleg, 2012).

PA has been consistently associated with enhanced well-being and QoL in later life (Netz et al., 2005). Different studies conducted on older adults from the general population have found that physical exercise may improve social interactions, self-esteem and global QoL. Furthermore, it may also contribute to increased independence in activities of daily living in older adults (Taylor et al., 2004; Warburton \& Bredin, 2017).

Flynn et al. (2009) have investigated the effects of exercise training on health status and QoL (assessed by the Kansas City Cardiomyopathy Questionnaire - KCCQ; Green, Porter, Bresnahan, \& Spertus, 2000) in 2,331 older adults with heart failure. The intervention included usual care plus aerobic exercise training, consisting of 36 supervised sessions followed by home-based training, compared to usual care alone. The results demonstrate that the participation in an exercise training program provides a modest but statistically significant improvement in patient-reported health status and QoL compared with usual care. Similarly, Austin and colleagues (2005) aimed to determine whether a cardiac rehabilitation programme improved health-related quality of life of 200 patients with heart failure aged 60 to 89. Patients were randomised to one of two interventions, outpatient clinic based care (standard care) or clinic based care plus cardiac rehabilitation, including a $24-$ week of low resistance training. Health-related 
Petra DOLENC, Mojca PETRIČ: PSYCHOLOGICAL BENEFITS OF EXERCISE AND PHYSICAL ACTIVITY IN OLDER ADULTS, 121-134

quality of life was measured with the Minnesota living with heart failure questionnaire (MLHF; Rector, Kubo, \& Cohn, 1993) and the EuroQoL questionnaire (Brooks $\&$ de Charro, 1996) at baseline and 24 weeks. Patients attending cardiac rehabilitation attained a significant improvement in health-related QoL compared to the patients in standard care.

To establish the association between PA and QoL in older adults, Vagetti and colleagues (2014) conducted a systematic review of the literature in the period between 2000 and 2012. In general, the studies included in this review showed a positive association between PA and many but not all domains of QoL. Results indicated that PA was often associated with the following QoL domains: functional capacity; general life autonomy; past, present and future activities; intimacy and mental health. These associations suggest that PA may promote physical independence as well as essential mental health aspects of QoL.

Although the results of recent literature suggest a positive and consistent influence on the relationship between PA and QoL in older adults, the mechanisms underlying these effects are still unclear. Self-efficacy - commonly defined as the belief in one's capabilities to achieve a goal or an outcome, appears to be an important variable that mediates the relationship between PA and QoL (Vagetti et al., 2014). Researchers have consistently shown that when PA is associated with significant increases in self-efficacy, improvements in health-related QoL are most likely to occur (Mudrak, Stochl, Slepicka, \& Elavsky, 2016). Efficacy beliefs also predict the behaviour and performance of older adults with mobility problems, balance difficulties, and are therefore at risk for falls (Rejski \& Mihalko, 2001; McAuley et al., 2011).

Furthermore, exercise and PA have been proposed to impact the QoL and well-being through their moderating and mediating effects on constructs such as self-concept and self-esteem. In particular, physical self-esteem has repeatedly been shown to be an important mental health status indicator in the context of PA and QoL relationship (Phillips, Wójcicki, \& McAuley, 2013).

PA and QoL play an important role in enhancing successful aging (Choi, Lee, Lee, \& Jung, 2017). According to Vagetti et al. (2014), evidence on the impact of PA frequency and intensity on QoL domains is still limited. Therefore, further longitudinal and intervention studies are needed to better understand this influence.

\section{CONCLUSION}

Growth in the elderly population means an increased risk for poor mental health outcomes such as depression, anxiety, and serious constraints on the QoL among older people. In recent years, a substantial body of literature has tried to explain the mental health benefits of PA in older adults. Although most of the studies discussed in this article report an inverse, dose-dependent relationship between PA participation and mental health outcomes, some questions remain unanswered, such as the right amount of exercise (e.g. frequency and intensity) to improve this protective response. Also, further 
studies using objective PA measures can contribute significantly to establish clear links between the amount of exercise and specific mental health benefits in older adults.

Regular PA and exercise are important for healthy aging and are beneficial for chronic disease management. However, there is evidence that as people age, they tend to exercise progressively less and most of them do not meet the recommended PA levels, particularly those living in less affluent areas (McPhee et al., 2016). Greater consideration of all psychological benefits of physical exercise is needed among health and exercise professionals working with the elderly. The main challenge is to find effective ways to encourage older adults to increase PA and reduce sedentary behaviour. It is therefore important to develop strategies to overcome barriers to exercise and stimulate participation in such activities that will be adapted to the needs and interests of older individuals.

\section{REFERENCES}

Ainsworth, B. E., Bassett, D. R., Strath, S. J., Swartz, A. M., O'Brien, W. L., Thompson, R., ... Kimsey, C. D. (2000). Comparison of three methods for measuring the time spent in physical activity. Medicine and Science in Sports and Exercise, 32(S9), S457464. VIEW ITEM

Arent, S. M., Landers, D. M., \& Etnier, J. L. (2000). The effects of exercise on mood in older adults: a meta-analytic review. Journal of Aging and Physical Activity, 8(4), 407430. doi: 10.1123/japa.8.4.407 VIEW ITEM

Austin, J., Williams, R., Ross, L., Moseley, L., \& Hutchison, S. (2005). A randomized controlled trial of cardiac rehabilitation in elderly patients with heart failure. European Journal of Heart Failure, 7, 411-417. doi: 10.1016/j.ejheart.2004.10.004 VIEW ITEM

Beck, A. T., Steer, R. A., \& Garbin, M. G. (1988). Psychometric properties of the Beck Depression Inventory: Twenty-five years of evaluation. Clinical Psychology Review, 8(1), 77-100. doi: 10.1016/0272-7358(88)90050-5 VIEW ITEM

Biswas, A., Oh, P. I., Faulkner, G. E., Bajaj, R. R., Silver, M. A., Mitchell, M. S., \& Alter, D. A. (2015). Sedentary time and its association with risk for disease incidence, mortality, and hospitalization in adults: a systematic review and meta-analysis. Annals of Internal Medicine, 162(2), 123-132. doi: 10.7326/M14-1651 VIEW ITEM

Blumenthal, J. A., Babyak, M. A., Moore, K. A., Craighead, W. E., Herman, S., Khatri, P. et al. (1999). Effects of exercise training on older patients with major depression. Archives of Internal Medicine, 159(19), 2349-2356. doi:10.1001/archinte.159.19.2349 VIEW ITEM

Blumenthal, J. A., Smith, P. J., \& Hoffman, B. M. (2012). Is exercise a viable treatment for depression? ACSM's health \& fitness journal, 16(4), 14-21. doi: 10.1249/01. FIT.0000416000.09526.eb VIEW ITEM

Bowling, A. (2005). Ageing well. Quality of life in older age. New York: Open University Press.

Bridle, C., Spanjers, K., Patel, S., Atherton, N. M., \& Lamb, S. E. (2012). Effect of exercise on depression severity in older people: systematic review and meta-analysis of ran- 
Petra DOLENC, Mojca PETRIČ: PSYCHOLOGICAL BENEFITS OF EXERCISE AND PHYSICAL ACTIVITY IN OLDER ADULTS, 121-134

domized controlled trials. British Journal of Psychiatry, 201(3), 180-185. doi: 10.1192/ bjp.bp.111.095174 VIEW ITEM

Brooks, R., \& de Charro, F. (1996). EuroQol: the current state of play. Health Policy, 37(1), 53-72. doi: 10.1016/0168-8510(96)00822-6 VIEW ITEM

Cho, J., Martin, P., Margrett, J., MacDonald, M., \& Poon, L. W. (2011). The relationship between physical health and psychological well-being among oldest-old adults. Journal of Aging Research, 60504. doi: 10.4061/2011/605041 VIEW ITEM

Chodzko-Zajko, W., Proctor, D. N., Fiatarone Singh, M. A., Minson, C. T., Nigg, C. R., Salem, G. J., \& Skinner, J. S. (2009). American College of Sports Medicine position stand. Exercise and Physical Activity for Older Adults. Medicine \& Science in Sports \& Exercise, 41(7), 1510-1530. doi: 10.1249/MSS.0b013e3181a0c95c VIEW ITEM

Choi, M., Lee, M., Lee, M. J., \& Jung, D. (2017). Physical activity, quality of life and successful ageing among community-dwelling older adults. International Nursing Review, 64(3), 396-404. doi: 10.1111/inr.12397 VIEW ITEM

Colcombe, S., \& Kramer, A. F. (2003). Fitness effects on the cognitive function of older adults: a meta-analytic study. Psychological Science, 14(2), 125-130. doi: 10.1111/14679280.t01-1-01430 VIEW ITEM

Conn, V. S. (2010). Depressive Symptom Outcomes of Physical Activity Interventions: Meta-analysis Findings. Annals of Behavioral Medicine: A Publication of the Society of Behavioral Medicine, 39(2), 128-138. doi: 10.1007/s12160-010-9172-x VIEW ITEM

Crone, D., Smith, A., \& Gough, B. (2009). The physical activity and mental health relationship - a contemporary perspective from qualitative research. Acta Gymnica, 36(3), 29-35. VIEW ITEM

Daskalopoulou, C., Stubbs, B., Kralj, C., Koukounari, A., Prince, M., \& Prina, A. M. (2017). Physical activity and healthy ageing: A systematic review and meta-analysis of longitudinal cohort studies. Ageing Research Reviews, 38, 6-17. doi: 10.1016/j. arr.2017.06.003 VIEW ITEM

DeBoer, L. B., Powers, M. B., Utschig, A. C., Otto, M. W., \& Smits, J. A. (2012). Exploring exercise as an avenue for the treatment of anxiety disorders. Expert review of neurotherapeutics, 12(8), 1011-1022. doi: 10.1586/ern.12.73 VIEW ITEM

Deslandes, A., Moraes, H., Ferreira, C., Veiga, H., Silveira, H., Mouta, R., ... Laks, J. (2009). Exercise and mental health: many reasons to move. Neuropsychobiology, 59, 191-198. doi: 10.1159/000223730 VIEW ITEM

Dishman, R. K., \& O'Connor, P. J. (2009). Lessons in exercise neurobiology: the case of endorphins. Mental Health and Physical Activity, 2(1), 4-9. doi: 10.1016/j. mhpa.2009.01.002 VIEW ITEM

Dyrstad, S. M., Hansen, B. H., Holme, I. M., \& Anderssen, S. A. (2014). Comparison of self reported versus accelerometer-measured physical activity. Medicine \& Science in Sports \& Exercise, 46(1), 99-106. doi: 10.1249/MSS.0b013e3182a0595f VIEW ITEM

Earnest, C. P., Johannsen, N. M., Swift, D. L., Lavie, C. J, Blair, S. N., \& Church, T. S. (2013). Dose-effect of cardiorespiratory exercise on metabolic syndrome in postmenopausal women. American Journal of Cardiology, 111(12), 1805-1811. doi: 10.1016/j. amjcard.2013.02.037 VIEW ITEM

Fleg, J. L. (2012). Aerobic exercise in the elderly: a key to successful ageing. Discovering Medicine, 13(70), 223-228. VIEW ITEM

Flynn, K. E., Piña, I. L., Whellan, D. J., Lin, L., Blumenthal, J. A., Ellis, S. J., ... Weinfrut, K. P. (2009). Effects of exercise training on health status in patients with chronic 
Petra DOLENC, Mojca PETRIČ: PSYCHOLOGICAL BENEFITS OF EXERCISE AND PHYSICALACTIVITY IN OLDER ADULTS, 121-134

heart failure: HF-ACTION randomized controlled trial. JAMA, 301(14), 1451-1459. doi: 10.1001/jama.2009.457 VIEW ITEM

Fox, K. R., Stathi, A., McKenna, J., \& Davis, M. G. (2007). Physical activity and mental well-being in older people participating in the Better Ageing Project. European Journal of Applied Physiology, 100(5), 591-602. doi: 10.1007/s00421-007-0392-0 VIEW ITEM

Gajewski, P. D., \& Falkenstein, M. (2016). Physical activity and neurocognitive functioning in aging - a condensed updated review. European Review of Aging and Physical Activity,13(1). doi: 10.1186/s11556-016-0161-3 VIEW ITEM

Gill, D. L., Hammond, C. C., Reifsteck, E. J., Jehu, C. M., Williams, R. A., Adams, M. M., ... Shang, Y.-T. (2013). Physical Activity and Quality of Life. Journal of Preventive Medicine and Public Health, 46(Suppl 1): S28-S34. doi: 10.3961/jpmph.2013.46.S.S28 VIEW ITEM

Green, C. P., Porter, C. B., Bresnahan, D. R., \& Spertus J. A. (2000). Development and evaluation of the Kansas City Cardiomyopathy Questionnaire: a new health status measure for heart failure. Journal of the American College of Cardiology, 35(5), 1245-1255. doi: 10.1016/s0735-1097(00)00531-3 VIEW ITEM

Jenkinson, C., Chandola, T., Coulter, A., \& Bruster, S. (2001). An assessment of the construct validity of the SF-12 summary scores across ethnic groups. Journal of Public Health Medicine, 23(3), 187-194. VIEW ITEM

Joshi, S., Mooney, S. J., Kennedy, G. J., Benjamin, E. O., Ompad, D., Rundle, A. G. et al. (2016). Beyond METs: types of physical activity and depression among older adults, Age and Ageing, 45(1), 103-109. doi: 10.1093/ageing/afv164 VIEW ITEM

King, A. C., \& King, D. K. (2010). Physical activity for an aging population. Public health reviews, 32(2), 401-426. doi: 10.1007/BF03391609 VIEW ITEM

Kokkinos, P. (2012). Physical activity, health benefits, and mortality risk. Cardiology, 718789. doi: 10.5402/2012/718789 VIEW ITEM

Lee, H., Lee, J.-A., Brar, J. S., Rush, E. B., \& Jolley, C. J. (2014). Physical activity and depressive symptoms in older adults. Geriatric Nursing , 35(1), 37-41. doi: doi: 10.1016/j.gerinurse.2013.09.005 VIEW ITEM

Linden, M., Borchelt, M., Barnow, S., \& Geiselman, B. (1995). The impact of somatic morbidity on the Hamilton Depression Rating Scale in the Very Old. Acta Psychiatrica Scandinavica, 92(2), 150-154. doi: 10.1111/j.1600-0447.1995.tb09559.x_VIEW ITEM

Lindwall, M., Rennemark, M., Halling, A., Berglund J., \& Hassmén, P. (2007). Depression and exercise in elderly men and women: findings from the Swedish national study on aging and care. Journal of Aging and Physical Activity, 15(1), 41-55. doi: 10.1123/ japa.15.1.41 VIEW ITEM

Litwin, H., \& Shiovitz-Ezra, S. (2011). Social network type and subjective well-being in a national sample of older Americans. The Gerontologist, 51(3), 379-388. doi: 10.1093/ geront/gnq094 VIEW ITEM

Loprinzi, P. D. (2013). Objectively measured light and moderate-to-vigorous physical activity is associated with lower depression levels among older US adults. Aging \& Mental Health, 17(7), 801-805. doi: 10.1080/13607863.2013.801066 VIEW ITEM

Lubans, D., Richards, J., Hillman, C., Faulkner, G., Beauchamp, M., Nilsson, M. et al. (2016). Physical activity for cognitive and mental health in youth: a systematic review of mechanisms. Pediatrics, 138(3) e20161642. doi: 10.1542/peds.2016-1642 VIEW ITEM 
Martin, A., Rief, W., Klaiberg, A., \& Braehler, E. (2006). Validity of the brief patient health questionnaire mood scale (PHQ-9) in the general population. General Hospital Psychiatry, 28(1), 71-77. doi: 10.1016/j.genhosppsych.2005.07.003 VIEW ITEM

Matta Mello Portugal, E., Cevada, T., Sobral Monteiro, R. Jr, Teixeira Guimarães, T., da Cruz Rubini, E., Lattari, E., ... Camaz Deslandes, A. (2013). Neuroscience of Exercise: From Neurobiology Mechanisms to Mental Health. Neuropsychobiology, 68(1), 1-14. doi: 10.1159/000350946 VIEW ITEM

McAuley, E., Mullen, S. P., Szabo, A. N., White, S. M., Wójcicki, T. R., Mailey, E. L., ... Kramer, A. F. (2011). Self-regulatory processes and exercise adherence in older adults: executive function and self-efficacy effects. American Journal of Preventive Medicine, 41(3), 284-290. doi: 10.1016/j.amepre.2011.04.014 VIEW ITEM

McPhee, J. S., French, D. P., Jackson, D., Nazroo, J., Pendleton, N., \& Degens, H. (2016). Physical activity in older age: perspectives for healthy ageing and frailty. Biogerontology, 17(3), 567-80. doi: 10.1007/s10522-016-9641-0 VIEW ITEM

Meléndez-Ortega, A. (2007). Osteoporosis, falls and exercise. European Review of Aging and Physical Activity, 4(2), 61-70. doi.org/10.1007/s11556-007-0027-9 VIEW ITEM

Mikkelsen, K., Stojanovska, L., Polenakovic, M., Bosevski, M., \& Apostolopoulos, V. (2017). Exercise and mental health. Maturitas, 106, 48-56. doi: 10.1016/j.maturitas.2017.09.003 VIEW ITEM

Mochcovitch, M. D., Deslandes, A. C., Freire, R. C., Garcia, R. F., \& Nardi, A. E. (2016). The effects of regular physical activity on anxiety symptoms in healthy older adults: a systematic review. Revista Brasileira de Psiquiatria, 38(3), 255-261. doi: 10.1590/1516-4446-2015-1893 VIEW ITEM

Mora, F. (2013). Successful brain aging: plasticity, environmental enrichment, and lifestyle. Dialogues in Clinical Neuroscience, 15(1), 45-52. VIEW ITEM

Mudrak, J., Stochl, J., Slepicka, P., \& Elavsky, S. (2016). Physical activity, self-efficacy, and quality of life in older Czech adults. European Journal of Ageing, 13(1), 5-14. doi: 10.1007/s10433-015-0352-1 VIEW ITEM

Mummery, W. K., Schofield, G., \& Caperchione, C. (2004). Physical Activity Dose Response Effects on Mental Health Status in Older Adults. Australia New Zealand Journal of Public Health, 28(2), 180-184. doi: 10.1111/j.1467-842X.2004.tb00934.x VIEW ITEM

Murtagh, E., Murphy, M., Murphy, N., Woods, C., \& Lane, A. (2014). Physical activity, ageing, and health. Centre for Ageing Research and Development in Ireland. Belfast, Ireland.Retrieved from http://www.cardi.ie/sites/default/files/publications/

Musich, S., Wang, S. S., Hawkins, K., \& Greame, C. (2017). The frequency and health benefits of physical activity for older adults. Population Health Management, 20(3), 199-207. doi: 10.1089/pop.2016.0071 VIEW ITEM

Netz, Y., Wu, M. J., Becker, B. J., \& Tenenbaum, W. (2005). Physical activity and psychological well-being in advanced age: a meta-analysis of intervention studies. Psychology and Aging, 20(2), 272-284. doi: 10.1037/0882-7974.20.2.272 VIEW ITEM

Parker, S. J., Strath, S. J., \& Swartz, A. M. (2008). Physical Activity Measurement in older adults: Impact on observation of relationships with mental health. Journal of Aging and Physical Activity, 16(4), 369-380. VIEW ITEM

Peluso, M. A., \& Andrade, L. H. (2005). Physical activity and mental health: the association between exercise and mood. Clinics, 60(1), 61-70. doi: 10.1590/S180759322005000100012 VIEW ITEM 
Petra DOLENC, Mojca PETRIČ: PSYCHOLOGICAL BENEFITS OF EXERCISE AND PHYSICALACTIVITY IN OLDER ADULTS, 121-134

Penninx, B. W., Rejeski, W. J., Pandya, J., Miller, M. E., Di Bari, M., Applegate, W. B., \& Pahor, M. (2002). Exercise and depressive symptoms: a comparison of aerobic and resistance exercise effects on emotional and physical function in older persons with high and low depressive symptomatology. The journals of gerontology. Series B, Psychological sciences and social sciences, 57(2), P124-132. VIEW ITEM

Phillips, S. M., Wójcicki, T. R., \& McAuley, E. (2013). Physical activity and quality of life in older adults: An 18-month panel analysis. Quality of Life Research, 22(7), 16471654. doi: 10.1007/s11136-012-0319-z VIEW ITEM

Radloff, L. S. (1977). The CES-D scale: A self report depression scale for research in the general population. Applied Psychological Measurements, 1(3), 385-401. doi: 10.1177/014662167700100306 VIEW ITEM

Rector, T. S., Kubo, S. H., \& Cohn, J. N. (1993). Validity of the Minnesota living with heart failure questionnaire as a measure of therapeutic response to enalapril or placebo. American Journal of Cardiology, 7(12), 1106-1107. doi: 10.1016/0002-9149(93)90582W VIEW ITEM

Reiner, M., Niermann, C., Jekauc, D., \& Woll, A. (2013). Long-term health benefits of physical activity - a systematic review of longitudinal studies. BMC Public Health, 13, 813. doi: 10.1186/1471-2458-13-813 VIEW ITEM

Rejski, W. J., \& Mihalko, S. L. (2001). Physical activity and quality of life in older adults. The journals of gerontology. Series A, Biological sciences and medical sciences, 56(S2), 23-35. doi: 10.1093/gerona/56.suppl_2.23_VIEW ITEM

Shaw, D., Gorely, T., \& Corban, R. (2005). Sport and exercise psychology. New York: BIOS Scientific Publishers.

Silveira, H., Moraes, H., Oliveira, N., Coutinho, E. S., Laks, J., \& Deslandes, A. (2013). Physical Exercise and Clinically Depressed Patients: A Systematic Review and MetaAnalysis. Neuropsychobiology, 67, 61-68. doi: 10.1159/000345160 VIEW ITEM

Stubbe, J. H., de Moor, M. H., Boomsma, D. I., \& de Geus, E. J. (2007). The association between exercise participation and well-being: A co-twin study. Preventive Medicine, 44(2), 148-152. doi: 10.1016/j.ypmed.2006.09.002 VIEW ITEM

Taylor, A. H., Cable, N. T., Faulkner, G., Hillsdon, M., Narici, M., \& Van Der Bij, A. K. (2004). Physical activity and older adults: a review of health benefits and the effectiveness of interventions. Journal of Sports Science, 22(8), 703-725. doi: 10.1080/02640410410001712421 VIEW ITEM

Toups, M. S., Greer, T. L., Kurian, B. T., Grannemann, B. D., Carmody, T. J., ...Trivedi, M. H. (2011). Effects of serum brain derived neurotrophic factor on exercise augmentation treatment of depression. Journal of Psychiatric Research, 45(10), 1301-1306. doi: 10.1016/j.jpsychires.2011.05.002 VIEW ITEM

Vagetti, G. C., Barbosa Filho, V. C., Moreira, N. B., de Oliveira, V., Mazzardo, O., \& de Campos, W. (2014). Association between physical activity and quality of life in the elderly: a systematic review, 2000-2012. Revista Brasileira de Psiquiatria, 36(1), 76-88. doi: 10.1590/1516-4446-2012-0895 VIEW ITEM

Warburton, D. E. R., \& Bredin, S. S. D. (2017). Health benefits of physical activity: a systematic review of current systematic reviews. Current Opinion in Cardiology, 32(5), 541-556. doi: 10.1097/HCO.0000000000000437 VIEW ITEM

Washburn, R. A., McAuley, E., Katula, J., Mihalko, S. L., \& Boileau, R. A. (1999). The physical activity scale for the elderly (PASE): evidence for validity. Journal of Clinical Epidemiology, 52(7), 643-651. doi: 10.1016/S0895-4356(99)00049-9 VIEW ITEM 
Watanabe, E., Takeshima, N., Okada, A., \& Inomata, K. (2000). Comparison of waterand land-based exercise in the reduction of state anxiety among older adults. Perceptual and Motor Skills, 91(1), 97-104. doi: 10.2466/pms.2000.91.1.97 VIEW ITEM

World Health Organization (2015). Global Strategy on Diet, Physical Activity and Health Physical Activity and Older Adults. Retrieved from http://www.who.int/dietphysicalactivity/factsheet olderadults/en/

World Health Organization (2016). Mental health of older adults Key facts. Retrieved from http://www.who.int/en/news-room/fact-sheets/detail/mental-health-of-older-adults

Wrosch, C., Schult, R., Miller, G. E., Lupien, S., \& Dunne, E. (2007). Physical health problems, depressive mood, and cortisol secretion in old age: Buffer effects of health engagement control strategies. Health Psychology, 26(3), 341-349. doi: 10.1037/02786133.26.3.341 VIEW ITEM 